\title{
Population policy: A concise summary
}

Paul Demeny

Population Council

Follow this and additional works at: https://knowledgecommons.popcouncil.org/departments_sbsr-pgy

Part of the Demography, Population, and Ecology Commons, Family, Life Course, and Society Commons, and the International Public Health Commons How does access to this work benefit you? Let us know!

\section{Recommended Citation}

Demeny, Paul. 2003. "Population policy: A concise summary," Policy Research Division Working Paper no. 173. New York: Population Council. 


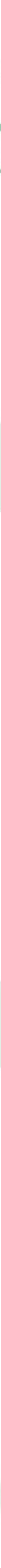




\title{
Population Policy: A Concise Summary
}

\author{
Paul Demeny
}

Paul Demeny is Distinguished Scholar, Population Council, New York.

Forthcoming in International Encyclopedia of Population, Paul Demeny and Geoffrey McNicoll, editors (New York: Macmillan Reference, 2003). 


\begin{abstract}
Population policies are deliberately constructed or modified institutional arrangements and/or specific programs through which governments influence, directly or indirectly, demographic change. For any given country, the aim of population policy may be narrowly construed as bringing about quantitative changes in the membership of the territorially circumscribed population under the government's jurisdiction. Governments' concern with population matters can also extend beyond the borders of their own jurisdictions. Thus, international aspects of population policy have become increasingly salient in the contemporary world. Additions to the population are primarily the result of individual decisions concerning childbearing. Within the constraints of their social milieu, these decisions reflect an implicit calculus by parents about the private costs and benefits of children. But neither costs nor benefits of fertility are likely to be fully internal to the family: they can also impose burdens and advantages on others in the society. Such externalities, negative and positive, represent a legitimate concern for all those affected. The paper briefly discusses how individual and collective interests were reconciled in traditional societies, summarizes the population policy approaches adopted by the classic liberal state, and sketches government responses to the low-fertility demographic regime that emerged in the West between the two World Wars. In greater detail it considers international population policies after World War II and contemporary population policy responses to below-replacement fertility.
\end{abstract}

This material may not be reproduced without written permission from the author. For a list of Policy Research Division Working Papers, including those available for downloading in PDF format, see www.popcouncil.org/publications/wp/prd/rdwplist.html. 
Population policy may be defined as deliberately constructed or modified institutional arrangements and/or specific programs through which governments influence, directly or indirectly, demographic change.

The generality of the definition lends itself to varying interpretations. For any given country, the aim of population policy may be narrowly construed as bringing about quantitative changes in the membership of the territorially circumscribed population under the government's jurisdiction. Additions to membership are effected only through births and immigration, losses are caused by emigration and by deaths. Concern with this last component is usually seen as a matter for health policy, leaving fertility and migration as the key objects of governmental interest in population policy.

More broadly, policy intent may also aim at modification of qualitative aspects of these phenomena — fertility and international migration-including the composition of the population by various demographic characteristics and the population's spatial distribution.

Furthermore, governments' concern with population matters can also extend beyond the borders of their own jurisdictions. International aspects of population policy have become increasingly salient in the contemporary world.

\section{Population CONTRol in TRADitional Societies}

Rulers of any political unit have a stake in the size and composition of the population over which they have authority, hence an incentive to try to influence demographic change in a desired direction. Thus "population policy" may be said to have a long history, starting at least with the empires of the ancient world. Greater numbers tended to connote greater wealth and power, at least for those at the apex of the social pyramid. Measures encouraging marriage and sometimes immigration testify to the prevailing populationist sentiment among rulers throughout history.

But the leverage of the weak premodern state over fertility in traditional societies was necessarily limited. The dominant influence setting the patterns of reproduction was located, instead, in a deeper layer of social interaction. Births, the key element affecting population change, are produced by individual couples-seemingly an intensely private affair yet one in which the immediate kin group and the surrounding local soci- 
ety in which that group is embedded have a material stake. All societies, if at varying degrees, grant a measure of self-sovereignty to their members. An individual has certain rights over his or her direction in life. But this is always subject to some constraints, not only biological but also social. Well before rights and obligations are formally codified in legal terms, they are established through spontaneous social interaction-a self-organizing process. Restrictions on freedom to act take the form of social expectations and pressures that individuals can ignore only at considerable personal costs to themselves. Typically, there is a strong expectation that men and women should marry and have children. Parental and kin obligations in the matter of bringing up children are well understood by all adults and informally enforced by the community. In most societies there is the expectation that children are to be born to married couples only; that a man can have one wife at a time; that a husband is obligated to support his wife and a father his children; and that he can expect reciprocal services from them. And informal rules shaped by community interest tend effectively to regulate the entry of foreigners.

The fabric of such demographically relevant behavioral stances, supported by internalized personal norms and buttressed by religious injunctions, is a product of social evolution; how effective such institutions are becomes an important determinant of societal success. As a classic statement of the British demographer Alexander CarrSaunders (1922: 223) put it, persons and groups of persons

are naturally selected on account of the customs they practise, just as they are selected on account of their mental and physical characters. Those groups practicing the most advantageous customs will have an advantage in the constant struggle between adjacent groups over those that practise less advantageous customs. Few customs can be more advantageous than those which limit the number of a group to the desirable number....[In the traditional society] there would grow up an idea that it was the right thing to bring up a certain limited number of children, and the limitation of the family would be enforced by convention.

Given the harsh biological and economic constraints premodern societies invariably experienced, that "desirable number" presupposed fairly high fertility: high enough 
to provide a sufficient margin of safety over mortality. Successful societies-societies that survived to the dawn of the modern era-thus obeyed the biblical injunction to be fruitful and multiply, even though such multiplication as a matter of historical record was necessarily very slow. But traditional demographic regimes resulting from spontaneous social interaction achieved modest growth rates at varying levels of fertility and mortality. Early modern Western Europe succeeded in maintaining a relatively low average level of mortality by means of keeping birth rates low, primarily by means of a fairly high average age of marriage and substantial proportions that remained permanently single. A contrasting pattern, such as in India, combined early and universal marriage and a consequent high level of fertility with slow population growth by virtue of death rates that were also high, approximating the level of the birth rate. With respect to the rate of population growth, these different combinations of birth and death rates in traditional societies were very similar. The potential for rapid population growth that might be triggered by a fall of mortality was, however, much higher when the premodern equilibrium was the result of a combination of high mortality and high fertility.

\section{Rationale for Population Policy}

Modernity - the rise of democratic state formations reflecting the public interest and the emergence of rapid economic development—brought about the realistic promise of realizing age-old human aspirations for a better life. The state increasingly came to be seen as an institution created by the voluntary association of free individuals to further their interests. The central function of the state was to produce public goods-goods that individuals cannot secure for themselves. The US Constitution, promulgated in 1789, articulated key items in the collective interest concisely and with universal validity. The aim of the Union formed by the People was, in the words of the Constitution's Preamble, to "establish Justice, insure domestic Tranquility, provide for the common defence, promote the general Welfare, and secure the Blessings of Liberty to ourselves and our Posterity." In pursuing such goals, regulation of immigration into a state's territory is clearly defined as a public good, thus delineating a particular role for population policy. And aggregate fertility may also be construed as a public good, if its level as determined by spontaneous social interaction is too high or too low in terms of the collective interest. 
The potential role of the state in regulating immigration is straightforward: individuals wishing to restrict or promote it cannot set up their own border patrols or issue entry visas. Individual preferences in the matter, however, are likely to differ. It is the task of the government to weigh and reconcile conflicting individual desires and come up with a policy deemed the best under the accepted rules of the political process.

To claim a role for the state in the matter of fertility is more problematic. Additions to the population are the result of a multitude of individual decisions concerning childbearing. Within the constraints of their social milieu, these decisions reflect an implicit calculus by parents about the private costs and benefits of children to them. But neither costs nor benefits of fertility are likely to be fully internal to the family: they can also impose burdens and advantages on others in the society. Such externalities, negative and positive, represent a legitimate concern for all those affected. An individual's influence on the fertility of other families, however, is very limited: there are no private markets offering preferred patterns of aggregate demographic processes to individual buyers. Remedying such market failure may then be attempted through intervention by the state so as to affect individual behavior in order to best serve the common good-the good of all individuals.

The earliest clear formulation of the population problem as a problem of coordination among individual preferences, hence establishment of the rationale for potential state intervention in the matter of fertility, was given by William Foster Lloyd, an Oxford mathematician and economist, in an essay published in 1833. In the spirit of the Malthusian concerns of his time, Lloyd (1833/1968: 22-23) envisaged the possibility of overpopulation even under conditions when all families have only the children they actually want and suggested the direction in which remedy ought to be sought:

The simple fact of a country being overly populous...is not, of itself, sufficient evidence that the fault lies in the people themselves, or a proof of the absence of a prudential disposition. The fault may rest, not with them as individuals, but with the constitution of society, of which they form part.

Population policy should therefore strive toward institutions and incentive systems-a 
constitution of society - that provide signals to individuals guiding them to behave in harmony with the collective interest.

\section{Population Policy in the Liberal State}

Technological progress and consequent improvements in the standard of living in modernizing societies result in a far more effective control of mortality than was possible in the traditional society. But the fall of the death rate accelerates the rate of population growth, which, in turn, could strain the capacity of the economic system to accommodate the increased population numbers. Falling living standards then would once again increase death rates, reestablishing an approximate balance between births and deaths at a low standard of living. This was the pessimistic central vision of T. R. Malthus's 1798 Essay. But this outcome, although held to be highly probable, was, according to Malthus, avoidable. Given sound public policies, there was an alternative to subsistence-level equilibrium, both agreeable and achievable.

A salient element in the 1798 Essay, and in subsequent writings influenced by it, was disapproval of the schemes for poor relief prevailing in Britain and elsewhere in Europe - on the grounds that they were likely to encourage irresponsible reproduction. Efforts of the paternalistic state to reduce poverty were held to be misguided; by stimulating fertility, hence population growth, such efforts would generate only more misery. Malthusians argued that the state's correct stance in demographic matters, as in the economy at large, was laissez faire. This would foster the prudential habits among the general population similar to those that already existed among the propertied classes. It would do so by assuring that the costs of childbearing were not shared by society at large but were primarily borne by the individual couples having children.

Heeding such a prescription did not imply that the state was to play a passive role in demographic matters. Malthus's own writings, most clearly his 1820 tract Principles of Political Economy (1989: 250-251), spell out a broad agenda which expresses the philosophy that came to be dominant in the liberal states of the West in the nineteenth century. Material improvements, such as higher wages for labor, could indeed be defeated if they would be "chiefly spent in the maintenance of large and frequent families." But Malthus also envisaged a different, happier possible outcome: "a decided 
improvement in the modes of subsistence, and the conveniences and comforts enjoyed, without a proportionate acceleration of the rate of [population] increase."

The possibility of such diametrically different responses to the stimulus of higher wages suggests a large element of indeterminacy in fertility behavior. To Malthus, the causes of these divergent responses were to be found in the circumstances, social and political, in which people lived - in particular, whether those circumstances hindered or rewarded planning for the future. From his analysis he derived a prescription for a population policy that would yield the hoped-for demographic outcome:

Of all the causes which tend to generate prudential habits among the lower classes of society, the most essential is unquestionably civil liberty. No people can be much accustomed to form plans for the future, who do not feel assured that their industrious exertions, while fair and honourable, will be allowed to have free scope; and that the property which they either posses, or may acquire, will be secured to them by a known code of just laws impartially administered. But it has been found by experience, that civil liberty cannot be secured without political liberty. Consequently, political liberty becomes almost equally essential. (ibid.)

During the long nineteenth century - which may be thought of as stretching to the outbreak of the First World War-the politics in Europe and in its overseas offshoots favored, even if imperfectly, the development of institutional and legal frameworks in harmony with such principles. This, in interaction with economic and cultural changes shaped by the industrial revolution, created a milieu that fostered the prudential habits of parents, rendering the micro-level calculus of the costs and benefits of children increasingly salient. Rising demand for labor, including greater use of child labor, and rising income levels tended to sustain high fertility or even to stimulate it. But rising material expectations, broadening opportunities for social mobility, and the patterns and circumstances of urban living pulled in the opposite direction. This was powerfully reinforced by some programmatic activities that were consistent with the limited role the liberal state claimed in managing the economy. These included public health programs and projects aimed at improving basic infrastructure for transport and 
communication. And most importantly, the state, or local government, assumed a key role in fostering, organizing, and financing public education. At basic levels school attendance was made mandatory and enforced and, in parallel, labor laws curtailed the employment of children.

Reflecting long-standing cultural values and religious injunctions, and contrary to laissez-faire principles, the liberal state generally banned the spreading of contraceptive information and the sale of contraceptive devices and made abortion illegal. Such restrictions typically remained in effect well into the twentieth century. But by all evidence, any upward pressure on fertility from these restrictions was swamped by the downward pressure on parental demand for children resulting from the state policies and programs just mentioned. By the last quarter of the nineteenth century birth rates were falling rapidly in the countries of the West. In many cases, rates of population growth fell also, despite continuing improvements in mortality. In Europe this trend was facilitated by emigration, which both sending and receiving countries-notably the United States, Canada, and Australia-either positively encouraged or at least permitted.

The stance of the liberal state on population policy thus brought about the prospect of a new demographic equilibrium in the West that could be consistent with continuing material progress: achievement of a stationary population at low levels of fertility and mortality and allowing freedom of movement internationally.

\section{Population Policy Between the World Wars}

The massive losses of life resulting from World War I and from the influenza pandemic in its immediate aftermath, and the sharp drop in the number of births during the war years, were temporary disruptions in the steadily declining trends of fertility and mortality characterizing the prewar decades in the West. Those trends soon made it evident that there is no built-in guarantee that the sum total of individual fertility decisions will eventually settle at a point at which, in the aggregate, the rate of population growth will be exactly zero or fluctuate tightly around a zero rate. Although, owing to relatively youthful age distributions, the rate of natural increase remained positive, by the late 1920s demographers realized that fertility rates in several Western countries had fallen to such a low level that, in the longer term, natural increase would become nega- 
tive. This trend became more accentuated and more general under the impact of the Great Depression. Some observers foresaw a "twilight of parenthood."

Just as excessive reproduction called for corrective public policies, there were calls for corrective action achieving the opposite result: enhancing fertility so as to assure at least the simple maintenance of the population. In some countries the ban on contraceptives was tightened and the penalties on abortion were increased. These measures had little effect. Neither did, predictably, governmental exhortation appealing to families to have more children.

The most promising avenue for population policy seemed to be to use the instruments available to the state for redistributing income so as to reward demographic behavior considered socially desirable (and to discourage contrary behavior). By the 1930s such pronatalist policies came to be fairly widely if rather tight-fistedly applied in a number of countries. Among Europe's emerging democratic welfare states, Sweden and France were pioneers in providing financial rewards and services in kind to families with children, especially to larger families. (Sweden, however, also allowed liberal access to contraception.) Similar policies were applied with equal or greater vigor in fascist Italy and Nazi Germany.

Invariably, the proponents of such policies claimed some results in terms of birth rates somewhat higher than would have been expected in their absence. But the latter quantity is a hypothetical one, which introduces a necessary caution to such claims. More pertinently, when average fertility is low, the birth rate in any given year is an unreliable measure of long-run fertility. Couples have considerable latitude to time the birth of their children earlier or later, without affecting the number of children they ultimately wish to have. Logically, pronatalist policies seek to affect that lifetime total rather than aiming at temporary increases in the birth rate.

\section{International Population Policy}

\section{AFTER WORLD WAR II}

In the countries that the United Nations categorizes as less developed, population policy issues attracted little attention until the middle of the twentieth century. Fertility remained high, more or less at its premodern level. Population growth was slowly in- 
creasing, however, as a result of improvements in mortality. Following the end of World War II, mortality decline accelerated greatly and as a result so did population growth. In 1950 , the world population was 2.5 billion. Some 1.7 billion of that total was in countries classified as less developed, with an average annual birth rate of 44 per 1000 population - twice as high as in the more developed group. Unless a decline of the birth rate got underway fairly rapidly, an unprecedentedly large expansion of human numbers was inevitable.

Although the trigger of such population growth was a welcome developmentfalling death rates - growth rates that would double or even treble a population within a generation seemed a major obstacle to development. And the large and widening differential between the more developed and the less developed countries in terms of population size and average income levels was seen as holding out the prospect of major dislocations and long-term instabilities within the international system. As a result, in the 1950s an intense debate started on what policies could reduce fertility in the less developed world. This policy debate was primarily Western, much of it American, just as the diagnosis of the problem itself had been. The proposals that emerged were to be applied in countries representing a large and growing share of the global population. Population policy became international.

The West of course already had relatively low fertility, and with it much historical experience on why birth rates fell. Social science analysis was virtually unanimous in interpreting this experience. The explanation centered on the role of changing structural conditions of the economy, conditions to which micro-level units of the population tended to respond, in demographic as well as in other matters. Demand for smaller families was seen as the primary force determining birth rates; the means by which couples regulated their fertility was not unimportant, but seen as a distinctly secondary factor. If the demand was strong enough, fertility would be low, even if birth control technology was primitive. A transition to low fertility presupposed changing preferences, and such preferences were responses to market signals. If policy was to have an explicit role, it would be through reinforcing those signals.

In the experience of past fertility transitions, four components of the incentive structure seemed especially pertinent: (1) the direct costs parents must incur in bringing 
up children; (2) the opportunity costs of children to parents, that is, the earnings a couple must forgo because of children; (3) the contribution of children to family income through labor services; and (4) the contributions of children to parents' economic security in old age, in comparison to alternative sources of security.

Fertility declines when shifts in these components make family limitation advantageous to couples, overcoming cultural resistance supporting traditional behavior. Patterns of development generate that effect when at least some, but especially when all of the following conditions are fulfilled: (1) social expectations and formal institutional arrangements place on parents the major financial responsibility for raising their own children, including much of the cost of education and health care; (2) women have access to income-earning opportunities in the labor market, including jobs not easily compatible with childbearing and childrearing; (3) social institutions make formal education (primary and early secondary) compulsory and effectively enforce school attendance; (4) child labor is made illegal; (5) effective legal guarantees of property rights, legal enforcement of private contracts, and the development of public and private insurance and pension schemes provide attractive and comparatively secure alternatives to children as a source of old-age security.

Social and institutional conditions that make such changes potent generators of fertility decline include the following: (1) emphasis on personal economic contribution (rather than, for example, class status or political loyalty) as the primary factor determining a person's earnings, thus providing an incentive for increased investment in human capital; (2) systems of promotion that provide opportunities for upward social mobility according to merit and tolerate downward social mobility; (3) openness to outside influences that create rising expectations with respect to material standards of living; and (4) emphasis not only on the rights but also on the social and economic responsibilities of the individual.

Some of the factors that prompted the fall of fertility in the West also became potent in the less developed countries as concomitants of successful economic and social progress. International conferences, for example the 1974 Bucharest conference on population, spelled out many of the essential socioeconomic changes necessary for fertility to shift from high to low levels. But assembling the instruments so identified into 
a coherent development strategy of institutional-structural reforms, reforms justified also by demographic objectives, remained an elusive task. In promoting development governments came to see their roles not in supporting institutions harnessing the market, but replacing the market in key developmental tasks through specific goal-oriented categorical programs. In the matter of population policy, the rapid postwar progress in the technology of birth control provided an appealing apparent short-cut for achieving fertility decline through programmatic means. Markets, it was held, could not be relied on to bring that technology to those wishing to practice birth control. Governments could, instead, organize free delivery of birth control information, and provide effective means for preventing births to all those, primarily (it was assumed) women, who wished to plan their families. Surveys indicated that there existed a substantial latent demand for such services. Satisfied customers, in turn, would serve as role models, bringing new clients to the program.

By the mid-1960s, in programmatic terms the international population policy debate on the relative importance of demand versus supply was essentially decided in favor of the latter. For the next quarter-century, population policy in the developing world became essentially synonymous with family planning programs.

Financial and administrative limitations within developing countries necessitated the heavy involvement of foreign assistance in launching and sustaining family planning programs. Although donor countries' own domestic experience in this area was practically nonexistent, such aid, justified by the seriousness of the "population problem" (a problem whose cause was defined in terms of aggregate indexes of population growth), was readily forthcoming, partly in the form of bilateral assistance and partly through international aid institutions.

The cost of birth control technology was, in itself, relatively modest. But sustaining an effective delivery service did represent significant claims on scarce human and material resources. Declared demand for birth control does not necessarily translate into effective willingness to practice it: conflicting desires may interfere. Weakness of measures of latent demand, or "unmet need," is reflected in the requirements that programs are supposed to satisfy if they are to be successful. These typically included such items as "doorstep accessibility of quality services," "broad choice of contraceptive meth- 
ods," "forceful IEC [information, education, and communication] programs," "sound financing strategies," "sound management with proper logistics," "evaluation systems," "a continuous process of strategic thinking, planning and management, " and "staff leadership for program parameters" (Mahler 1992: 5).

The effectiveness of family planning programs in reducing fertility remains a matter of controversy. According to international guidelines, programs recruit their clients on a strictly voluntary basis. By accepting the service voluntarily, the individual acceptor demonstrates that she values that service. But some of the more successful programs, notably in Asia, tended to increase acceptance by often heavy-handed methods of persuasion, and, in the especially important case of China, by coercion backed by legal sanctions. Where fertility fell in less developed countries with active family planning programs, it is typically found that program-provided free services account for a large percentage of those practicing contraception. This non-surprising result is then often taken as an indicator of success in reducing aggregate fertility. But what would have happened in the absence of the program is conjectural, hence routinely ignored. Some less developed countries that lacked government programs also experienced major falls of fertility: Brazil is a conspicuous example. Similarly, if programs have seemingly only minor success in reducing fertility, this can be taken as evidence that the program is inadequately financed, organized, and managed: greater efforts would have led to better results.

Family planning programs as they were commonly conceived had a strong resemblance to health programs. But given the special priority accorded to family planning services in foreign assistance, typically they were organized as a separate "vertical" program, or kept administratively distinct within the broad health program. The justification for such treatment was that while acceptors of family planning services are recruited because the program satisfies their individual need, the program also serves a national developmental need by helping to reduce aggregate population growth, hence deserves priority. Once a family planning program is organized, its managerial and professional cadres form a natural advocacy group strongly interested in the program's sustenance. Invoking the public interest in lowered fertility, as distinct from simply serving the needs of the clients of the program, has long served as a key supporting argument in that endeavor. 
Over time, this developmental prop has eroded. This was in part a result of criticisms of the intrinsic scientific merit of the argument but most of all a reflection of the extensive decline of fertility that has occurred, a decline often attributed to the success of the family planning programs themselves. On the eve of the 1994 International Conference on Population and Development, a review, considered highly respectful of the importance of fertility decline for successful development, reached the guarded conclusion that the data on the subject "mostly support the view that rapid population growth in poor countries under conditions of high fertility is inimical to many development goals"-with stress on the qualifying words "mostly," "high fertility," "many development goals," and "rapid," and with the last-mentioned term defined as "in excess of 2 percent annually" (Cassen 1994: 13). By that time, among world regions, only Africa and West Asia had a population growth rate meeting that criterion.

Accordingly, the development rationale of family planning programs was gradually dropped and was replaced by the argument that the programs satisfy important health needs and help people exercise a fundamental human right. The Cairo conference formalized this shift: even though the name of the conference for the first time included a reference to development, scant attention was paid to that concept. Family planning programs were redefined, instead, as reproductive health programs, responding to a broader range of women's health needs, such as prevention of unsafe abortions and sexually transmitted diseases, including HIV/AIDS. But beyond this, new emphasis was put on some requirements that would contribute to women's empowerment: reduction of infant and maternal mortality and improvement in girls' education and women's opportunities for employment and political participation. Although the connection was not highlighted, these are conditions that are likely to help reduce the birth rate through stimulating the demand for smaller family size. The Cairo conference, in effect, reverted to some key elements of a demand strategy for reducing birth rates.

The future of family planning service programs is thus left in a somewhat tenuous status. Without invoking a collective interest in a wider practice of birth control, it is not clear what level of priority should be accorded to such programs as just one part of publicly financed health programs, or indeed relative to many other social welfare programs that also serve demonstrable human needs. Not surprisingly, there are increasing 
efforts in national programs to rely on the market in enhancing access to contraceptives and to provide program services on a fee-for-service basis.

\section{Population Policy in Response to BELOW-REPLACEMENT FERTILITY}

During the second half of the twentieth century debates about population policy, and consequent programmatic action, were centered on the issue of rapid population growth in the less developed world. Toward the end of this period, however, a quite different demographic phenomenon has begun to attract increasing attention: aggregate fertility levels that are inadequate for the long-run maintenance of the population. Analytically, the potential population policy issue raised by low fertility is identical to the problem inherent in rapid population growth: it is caused by the disjunction between the sum total of individual reproductive decisions and the collective interest in a long-run demographic equilibrium. But this time individual aspirations generate a deficit rather than an excess in population growth. The syndrome, as was noted above, is not entirely novel: it was detectable in fertility trends in the West, especially in Europe, in the 1920s and 1930s, and in some instances, notably in France, even earlier. But in the decades immediately following World War II, the baby boom seemed to make the issue of low fertility moot. Indeed, by any historical standard, population growth was rapid during the second half of the twentieth century even in the developed world. Europe's population, for example, grew during that period from 550 million to about 730 million.

The baby boom was, however, a temporary interruption of the secular downward trend in fertility. By the 1970s, the net reproduction rate was at or below unity in most countries in Europe and also in the United States. In the US fertility stabilized at or very close to that rate, but in Europe fertility continued to decline. By the beginning of the twenty-first century, the average total fertility rate in Europe was 1.4. Such a level, if maintained indefinitely, would result in a population loss of one-third from generation to generation, that is, roughly, over each period of some 30 years. In some countries, notably in Southern, Central, and Eastern Europe, period fertility rates were at low levels without historical precedent for large populations. If continued, in the absence of large compensatory immigration this would not only lead to rapid population decline 
but also result in very high proportions of the population at old ages. It might be expected that in the affected countries such prospects would generate not only concern, but also vigorous remedial policy action.

By and large, however, this response has not been evident. Most governments as well as the general public tend to view below-replacement fertility with an equanimity quite unlike the alarmed reaction that the same phenomenon elicited when it first emerged between the two World Wars. And explicit pronatalist policies, common in the 1930s, are conspicuous by their absence. There are a variety of reasons explaining this indifference.

First, the preeminent population issue confronting policymakers in the post-World War II period was rapid global population growth. Programs aimed at moderating fertility in the developing world received assistance or at least encouragement from the rich, low-fertility countries. Although the rationale was modified over time, such assistance and encouragement have continued, as indeed substantial further population increase in the less developed countries is still anticipated in the early decades of the twenty-first century. Even though population issues tend to be sui generis, reflecting differences in demographic behavior country-by-country, there was, and remains, a perceived dissonance between fertility-lowering assistance to other countries and engaging in action at home serving the opposite aims. Faulty logic notwithstanding, the international terrain has not been favorable for domestic pronatalism.

Second, the natural rate of increase - the difference between the number of births and the number of deaths-is still positive in many of the countries with fertility well below replacement. This is the result of age distributions-reflecting past fertility and mortality and notably the effects of the postwar baby boom - that still favor population growth. While this momentum effect is temporary, the longer-term implications for population decline and population aging are only dimly perceived by the general public and provide an excuse for inaction on the part of policymakers.

Third, when those longer-term demographic effects are understood, a calmer attitude still prevails. There is an inclination, reinforced by increasing concern with the quality of the natural environment, to regard a degree of demographic "decompression" as a not necessarily unwelcome prospect, especially in countries with an already dense population. And it is assumed that the economic and social disadvantages that might be 
imposed by a declining population can be effectively dealt with through institutional adjustments and social policy measures other than measures aiming for a higher birth rate. A demographic policy often regarded as potentially helpful in this regard is encouragement of immigration. That willing immigrants are available to compensate for low birth rates is taken for granted - a realistic assumption in high-income countries.

Fourth, there is a vague expectation that the population decline, impending or already begun, will in due course trigger corrective homeostatic mechanisms, leading to a spontaneous rebound in the level of fertility. Another baby boom may not be in the offing, but fertility may rise sufficiently to once again reach or at least approximate replacement level. Governments, it is assumed, would be ill-advised to interfere with this natural process by trying to increase birth rates and then seeking to fine-tune them at the desirable steady-state level. According to this view, a laisser-faire fertility policy is justified since, apart from broad upper and lower limits, governments are not competent to determine what constitutes an optimal fertility rate, or growth rate, or population size in any given year, decade, or even longer time interval.

Finally, even if the will were there, there is a paucity of effective pronatalist policy instruments. Exhortation from governments is not promising, and in any case unlikely to be tried in a democratic polity. Restrictions imposed on access to modern contraceptive technology are not politically acceptable; they would be also certain to prove a failure. This leaves the traditional levers of social policy: dispensing material incentives and disincentives so as to increase the willingness of couples to have children. Such incentives can be engineered by the government through fiscal measures, such as differential taxation, and/or through provision of services in kind. This approach was tried in the interwar years, but, as noted above, with at best limited success. After World War II many similar measures continued to be applied; in fact, with the steadily expanding welfare state, they were often upgraded and their scope, too, was extended. However, they were no longer considered "pronatalist" but were absorbed within the more encompassing frames of family and general welfare policy. The new label partly reflected a political-ideological preference, but in part also the fact that some distinctive features of pronatalism—such as differential rewards that favored large families, and non-means-tested or even regressive allocation of family and child benefits-were generally no longer acceptable. 
Although the redistributive policies of the contemporary welfare state are biased in favor of the elderly and the poor, government-organized transfers to parents of children, or to children directly (such as through publicly financed day-care services and free or subsidized education often beyond the secondary school level, which lessen the cost of children to parents), are substantial in all low-fertility countries. Indeed, it is typically assumed that existing family and welfare policies sustain fertility above a level that would ensue in their absence. Accordingly, making these policies more generous-socializing an even larger share of child costs - is often seen as a means toward increasing fertility, whether as an outright policy objective or, more in the prevailing spirit of the time, as an unintended but welcome byproduct. Such extension, however, is difficult, given the fiscal constraints of already overcommitted welfare states. And more to the point, the net effect of familyfriendly redistribution of incomes and provision of services is uncertain. It is notable that in the US, where such schemes are distinctly less well funded than, for example, in Western Europe, fertility is, nevertheless, relatively high.

In recent decades, in modern industrial economies, participation of women in the formal labor force expanded rapidly. This tendency, reflecting market forces but also encouraged by government policy (partly as an antidote for deteriorating dependency ratios as the population becomes older), is likely to continue. Among the factors explaining the low level of fertility despite general material affluence, many observers point to the double burden on women of both raising children and working outside the home. To the extent that higher birth rates are seen to be socially desirable, the derived policy prescription is to adopt measures that make motherhood and women's labor force participation more compatible. The higher fertility in countries (notably in Scandinavia) where such measures are strongly applied, compared to countries (especially those in Southern Europe) where they are largely absent, suggests that enhanced compatibility (through day-care services, flexible work-hours, liberal sick-leave allowances, and the like) is an effective pronatalist policy even if motivated by other considerations. But it is far from clear whether the fertility differential so generated is high enough to bring the total fertility rate back to replacement level. Steady labor force participation of women during the childbearing years can certainly be made compatible with having one child or even two. It is likely to be far less compatible with sustaining, or even increasing, the proportion of women who have more than two children. Many career-oriented women 
voluntarily remain childless; many others prefer a single child. It follows that, to achieve average replacement-level fertility, the proportions of such women need to be counterbalanced by high enough proportions of women who have chosen third-, fourth-, or even higher-order births. There is little indication at present that policies directed at enhanced compatibility achieve that result.

When fertility is high, as it still is in most developing countries, it is a safe prediction that with economic development it will eventually decline, at least to replacement level. Since population growth cannot be sustained indefinitely, in the longer term, apart from outmigration, the only alternative is higher mortality. The record of the high-income countries indicates, however, that replacement-level fertility is not a necessary resting point. Once fertility is lower than that, predictions become highly hazardous. European and also East Asian experience suggests that fertility has a tendency to settle below an average of two children per woman, hence a tendency toward sustained population decline. The question, to which no good answers exist at the dawn of the twentyfirst century, is "how far below?" "Scandinavian"-style family policies may stabilize fertility only modestly below replacement—such as around a total fertility rate of 1.8 . That would imply a fairly moderate relative shortfall of births compared to deaths, and population stability in rich countries with such vital rates could be fully or nearly compensated with a modest level of controlled immigration. Population aging would be then kept within relatively narrow limits, which postindustrial economies could readily adjust to. The demographic weight of such countries within the global total in the foreseeable future would continue to shrink, raising possible problems of a shifting geopolitical balance. Still, such demographic configurations would be likely to push the day of demographic reckoning beyond the policy horizons that governments feel an obligation to be actively concerned with. Pronatalist interventions would find at best a marginal place on governments' policy agendas.

On the other hand, fertility levels in the lowest-fertility countries-countries with a total fertility rate of 1.3 or below around the turn of the century-might stabilize at that level, or even shrink further, reflecting the decentralized and uncoordinated decisions of individuals and individual couples. Such an outcome might also foreshadow future reproductive behavior in countries in which fertility is still fairly close to replace- 
ment level. This would create a qualitatively different demographic situation for which there are few precedents in modern history. It would represent a clear threat to the continuing viability of the countries affected. Compensatory immigration flows would have to be so large as to be inconsistent with any reasonable degree of cultural and ethnic continuity. Alternatively, population aging in the absence of immigration would create virtually unsolvable challenges, and there would be a likely drastic loss of relative geopolitical status. Spontaneous homeostatic mechanisms may not come into play to save the day, or may do so too sluggishly to matter. A radical rethinking of fertility policy would then become a necessity for social—and national—survival.

\section{BIBLIOGRAPHY}

Bauer, P. T. 1981. Equality, the Third World, and Economic Delusion. Cambridge, MA: Harvard University Press.

Berelson, Bernard. 1969. "Beyond family planning," Studies in Family Planning, No. 38.

Blake, Judith. 1972. "Coercive pronatalism and American population policy," in U. S., Commission on Population Growth and the American Future, Aspects of Population Growth Policy, Robert Parke, Jr. and Charles F. Westoff, eds. Vol. VI of Commission research reports, Washington, DC: Government Printing Office, pp. 85-109.

Bongaarts, John. 1994. "Population policy options in the developing world," Science 263: 771-776.

Carr-Saunders, A. M. 1922. The Population Problem: A Study in Human Evolution. Oxford: Clarendon Press.

Cassen, Robert and contributors. 1994. Population and Development: Old Debates, New Conclusions. Washington, DC: Overseas Development Council.

Casterline, John B. and Steven W. Sinding. 2000. "Unmet need for family planning in developing countries and implications for population policy," Population and Development Review 26:691-723. 
Chesnais, Jean-Claude. 1996. "Fertility, family, and social policy in contemporary Western Europe," Population and Development Review 22:729-739.

Cross, Máire and Sheila Perry, eds. 1997. Population and Social Policy in France. London and Washington: Pinter.

Davis, Kingsley. 1967. "Population policy: Will current programs succeed?" Science 158: 730-739.

Davis, Kingsley, Mikhail S. Bernstam, and Rita Ricardo-Campbell, eds. 1987. BelowReplacement Fertility in Industrial Societies: Causes, Consequences, Policies. Cambridge: Cambridge University Press.

Demeny, Paul 1986. "Population and the invisible hand," Demography 23:473-487.

Demeny, Paul. 1988. "Social science and population policy," Population and Development Review 14:451-479.

Demeny, Paul. 1992. "Policies seeking a reduction of high fertility: A case for the demand side," Population and Development Review 18: 321-332.

Donaldson, Peter J. 1990. Nature Against Us: The United States and the World Population Crisis, 1965-1980. Chapel Hill, NC: The University of North Carolina Press.

Finkle, Jason L. and Barbara B. Crane. 1975. "The politics of Bucharest: Population, development, and the new international economic order," Population and Development Review 1: 87-114.

Finkle, Jason L. and C. Alison McIntosh, eds. 1994. The New Politics of Population: Conflict and Consensus in Family Planning. Supplement to Vol. 20 of Population and Development Review.

Glass, D. V. 1940. Population: Policies and Movements in Europe. Oxford: Clarendon Press.

Gwatkin, Davidson R. 1979. "Political will and family planning: The implications of India's emergency experience," Population and Development Review 5: 29-59.

Hardin, Garrett. 1968. "The tragedy of the commons," Science 162: 1243-1248.

Hartmann, Betsy. 1995. Reproductive Rights and Wrongs: The Global Politics of Population Control. (Revised edition.) Boston: South End Press. 
Hodgson, Dennis. 1983. "Demography as social science and policy science," Population and Development Review 9: 1-34.

Johansson, S. Ryan. 1991. “'Implicit' policy and fertility during development," Population and Development Review 17: 377-414.

Lloyd, W. F. 1968 [1833]. "Two lectures on the checks to population," in Lectures on Population, Value, Poor Laws and Rent. New York: Augustus M. Kelley.

Mahler, Halfdan. 1992. "Our next forty years," People 19: 3-6.

Malthus, T. R. 1820. Principles of Political Economy. London: John Murray.

McIntosh, C. Alison and Jason L. Finkle. 1995. "The Cairo conference on population and development: A new paradigm?" Population and Development Review 21:223-260.

McNicoll, Geoffrey. 1975. "Community-level population policy: An exploration," Popиlation and Development Review 1: 1-21.

McNicoll, Geoffrey. 2001. "Government and fertility in transitional and post-transitional societies," Population and Development Review, Supplement to Vol. 27, pp. 129-159.

Myrdal, Alva. 1941. Nation and Family: The Swedish Experiment in Democratic Family and Population Policy. London: Routledge.

National Research Council. 1986. Population Growth and Economic Development: Policy Questions. Working Group on Population Growth and Economic Development, Committee on Population. Washington, DC: National Academy Press.

Olson, Mancur, Jr. 1965. The Logic of Collective Action. Cambridge, MA: Harvard University Press.

Pfenning, Astrid and Thomas Bahle, eds. 2000. Families and Family Policies in Europe: Comparative Perspectives. Frankfurt am Main: Peter Lang.

Pritchett, Lant H. 1994. "Desired fertility and the impact of population policies," Рориlation and Development Review 20:1-55.

Teitelbaum, Michael S. and Jay M. Winter. 1985. The Fear of Population Decline. San Diego: Academic Press. 
Teitelbaum, Michael S. and Myron Weiner, eds. 1995. Threatened Peoples, Threatened Borders: World Migration and U. S. Policy. New York: W. W. Norton.

United Nations, Department of Economic and Social Affairs, Population Division. 1999. Below Replacement Fertility. Population Bulletin of the United Nations. Special Issue, Nos. 40/41.

United Nations, Department of Economic and Social Affairs, Population Division. 2001. Replacement Migration: Is It a Solution to Declining and Ageing Populations? New York: United Nations.

United Nations, Department of Economic and Social Affairs, Population Division. 2002. National Population Policies 2001. New York: United Nations.

US National Academy of Sciences. 1971. Rapid Population Growth: Consequences and Policy Implications. Washington, DC: National Academy Press.

Warwick, Donald P. 1982. Bitter Pills: Population Policies and Their Implementation in Eight Developing Countries. New York: Cambridge University Press.

Winckler, Edwin A. 2002. "Chinese reproductive policy at the turn of the millennium: Dynamic stability," Population and Development Review 28: 379-418. 


\title{
POLICY RESEARCH DIVISION WORKING PAPERS
}

\author{
Recent Back Issues
}

144 John Bongaarts, "Household size and composition in the developing world."

145 John B. Casterline, Zeba A. Sathar, and Minhaj ul Haque, "Obstacles to contraceptive use in Pakistan: A study in Punjab."

146 Zachary Zimmer, Albert I. Hermalin, and Hui-Sheng Lin, "Whose education counts? The impact of grown children's education on the physical functioning of their parents in Taiwan."

147 Philomena Nyarko, Brian Pence, and Cornelius Debpuur, "Immunization status and child survival in rural Ghana."

*148 John Bongaarts and Zachary Zimmer, "Living arrangements of older adults in the developing world: An analysis of DHS household surveys."

149 Markos Ezra, "Ecological degradation, rural poverty, and migration in Ethiopia: A contextual analysis."
150 Cynthia B. Lloyd, Sahar El Tawila, Wesley H. Clark, and Barbara S. Mensch, "Determinants of educational attainment among adolescents in Egypt: Does school quality make a difference?"

151 Barbara S. Mensch, Paul C. Hewett, and Annabel Erulkar, "The reporting of sensitive behavior among adolescents: A methodological experiment in Kenya."

152 John Bongaarts, "The end of the fertility transition in the developed world."

153 Mark R. Montgomery, GebreEgziabher Kiros, Dominic Agyeman, John B. Casterline, Peter Aglobitse, and Paul Hewett, "Social networks and contraceptive dynamics in southern Ghana."

*154 Paul C. Hewett and Mark R. Montgomery, "Poverty and public services in developing-country cities."

* No longer available 
155 Zachary Zimmer, Linda G. Martin, and Ming-Cheng Chang, "Changes in functional limitations and survival among the elderly in Taiwan: 1993, 1996, and 1999."

156 John Bongaarts and Griffith Feeney, "How long do we live?"

157 Zachary Zimmer and Sovan Kiry Kim, "Living arrangements and socio-demographic conditions of older adults in Cambodia."

158 Geoffrey McNicoll, "Demographic factors in East Asian regional integration."

159 Carol E. Kaufman, Shelley Clark, Ntsiki Manzini, and Julian May, "How community structures of time and opportunity shape adolescent sexual behavior in South Africa."

*160 Julia Dayton and Martha Ainsworth, "The elderly and AIDS: Coping strategies and health consequences in rural Tanzania."

161 John Bongaarts, "The end of the fertility transition in the developing world."
162 Naomi Rutenberg, Carol E. Kaufman, Kate Macintyre, Lisanne Brown, and Ali Karim, "Pregnant or positive: Adolescent childbearing and HIV risk in South Africa."

163 Barbara S. Mensch, Wesley H. Clark, and Dang Nguyen Anh, "Premarital sex in Vietnam: Is the current concern with adolescent reproductive health warranted?"

164 Cynthia B. Lloyd, Cem Mete, and Zeba A. Sathar, "The effect of gender differences in primary school access, type, and quality on the decision to enroll in rural Pakistan."

165 Kelly Hallman, Agnes R. Quisumbing, Marie Ruel, and Bénédicte de la Brière, "Childcare, mothers' work, and earnings: Findings from the urban slums of Guatemala City."

*166 Carol E. Kaufman and Stavros E. Stavrou, "Bus fare, please': The economics of sex and gifts among adolescents in urban South Africa."

*167 Dominic K. Agyeman and John B. Casterline, "Social organization and reproductive behavior in southern Ghana."

* No longer available 
168 Paul C. Hewett, Annabel S. Erulkar, and Barbara S. Mensch, "The feasibility of computer-assisted survey interviewing in Africa: Experience from two rural districts in Kenya."

169 Zachary Zimmer and Julia Dayton, "The living arrangements of older adults in sub-Saharan Africa in a time of HIV/AIDS."

170 Ravai Marindo, Steve Pearson, and John B. Casterline, "Condom use and abstinence among unmarried young people in Zimbabwe: Which strategy, whose agenda?"
171 Sajeda Amin and Nagah H. AlBassusi, "Wage work and marriage: Perspectives of Egyptian working women."

172 Zachary Zimmer, Napaporn Chayovan, Hui-Sheng Lin, and Josefina Natividad, "How indicators of socioeconomic status relate to physical functioning of older adults in three Asian societies."

173 Paul Demeny, "Population policy: A concise summary." 


\title{
Population Policy: A Concise Summary
}

\author{
Paul Demeny
}

2003 No. 173 